\title{
A FORMAÇÃO DE DOCENTES PARA O ENSINO RELIGIOSO NO BRASIL: leituras e tessituras ${ }^{1}$
}

\section{La formación de los docentes para la enseñanza religiosa en Brasil: lecturas e contexto}

Lilian Blanck de Oliveira ${ }^{2}$

\section{Resumo}

Historicamente as relações estabelecidas entre Educação, Estado e Igreja em território brasileiro teceram a identidade do Ensino Religioso e a formação de docentes para esta disciplina no curnículo escolar. A homologação da nova redação do artigo trinta e três (Lei n. 9.475/97) da Lei de Diretrizes e Bases da Educação Nacional (LDBEN) n. 9.394/96 desafiou novas leituras e encaminhamentos à disciplina e conseqüente formação de docentes para esta área do conhecimento. Uma leitura histónica encaminha o presente texto, com o intuito de contribuir nas reflexões, estudos e discussões em relação às tramas, tecidos e tessituras, que configuram e conjugam a formação de docentes para o Ensino Religioso na atualidade brasileira.

Palavras-chave: História - Educação - Formação de Professores - Ensino Religioso.

1 O presente texto toma como referência o primeiro capítulo da tese de doutorado da autora: Formação de docentes para o Ensino Religioso: perspectivas e impulsos a partir da ética social de Martinho Lutero.

2 Doutora em Teologia - Área: Educação e Religião. Pedagoga e especialista nas Séries Iniciais do Ensino Fundamental e Educação Pré-Escolar. Coordenadora do Curso de Ciências da Religião - Licenciatura em Ensino Religioso e Curso de Pós-Graduação em nível de Especialização em Fundamentos e Metodologia de Ensino Religioso e pesquisadora no Programa de Mestrado de Desenvolvimento Regional da Fundação Universidade Regional de Blumenau - FURB.

E-mail: lilianbo@uol.com.br 


\section{Resumen}

Historicamente lãs relaciones establecidas entre la Educacion, el Estado y la Iglecia em território brasilero, tejieron la identidad de el Enseño Religioso y la formacion de los docentes de esta matéria para el curriculum escolar. La homologacion de la nueva redaccion del articulo treinta y tres (Ley n- 9.475/ 97) de la Ley de Directrises y Bases de la Educacion (LDBEN) para la formacion de docentes de esta matéria de la educacion. Uma lectura histórica encamina el presente texto, com el intuito de contribuir en las reflecciones, estúdios y discuciones en relacion a los diferentes asuntos de este tema y aquellos que configuran y conjugan la formacion de los docentes para el Enseño Religioso en la actualidad brasilera.

Palabras-clave: História; Educación; Formacion de los docentes; Enseño Religioso.

História não é a sucessão das conquistas do poder e dos atos do poder, mas é o encadeamento das responsabilidades do poder no decorrer do tempo.

(Buber, 1982)

O amplo processo de discussão envolvendo a educação nacional desencadeado na década de oitenta culminou na reforma do sistema educativo brasileiro, numa perspectiva organizativa e curricular na forma da promulgação da LDBEN n. 9.394/96. As discussões desenvolvidas assim como a emissão do dispositivo legal atingiram de modo substancial o processo de formação de docentes para todas as áreas do conhecimento na educação brasileira.

A partir da alteração do artigo 33 da LDBEN n. 9.394/96 (Lei n. 9.475/97), a formação de docentes para a disciplina de Ensino Religioso na Educação Fundamental tem se constituído em foco de interesse, discussão e pesquisa em âmbito nacional; envolvendo lideranças de diferentes denominações religiosas, a comunidade acadêmica e os sistemas de ensino, todos diretamente atingidos pelo dispositivo legal.

Historicamente o processo de formação de docentes para o Ensino Religioso no Brasil esteve diretamente ligado ao processo formador dos agentes pastorais das Instituições Religiosas que detinham a incumbência de desenvolver o processo educativo para esta área do conhecimento nas unidades escolares. 
Para Figueiredo (1996, p.5), a reflexão iniciada na década de setenta com a promulgação e implantação da Lei n. 5.692/71, que apresentava o Ensino Religioso como oferta obrigatória por parte da Unidade Escolar, dando ao aluno o direito de opção, gerou

um salto de qualidade na busca da identidade do ER, com distinção entre ER na escola e catequese na comunidade eclesial. Criaram-se programas de formação de professor e curriculares em que aspectos antropológicos, sociológicos, pedagógicos e políticos foram evidenciados, deixando para trás conteúdos doutrinários e práticas desvinculadas da experiência científica e cultural.

De acordo com as pesquisas de Junqueira (2002, essa discussão amadureceu nos trâmites da presente legislação de ensino (LDBEN n. 9.394/96) e na elaboração dos Parâmetros Curriculares Nacionais de Ensino Religioso (PCNER). A instituição das Diretrizes Curriculares Nacionais para o Ensino Fundamental (Resolução CEB n. 02/98) contemplou as aspirações e necessidades da atual sociedade brasileira no que diz respeito à disciplina de Ensino Religioso.

O presente texto procura refletir, de forma breve, a trajetória e as relações estabelecidas entre Educação, Estado e Igreja em território brasileiro, assim como a conseqüente posição do Ensino Religioso e a formação de docentes para esta disciplina curricular nesse processo histórico. O tema é apresentado em forma de períodos. Inicialmente essas questões se encontram circunscritas ao período colonial, sendo seguidas de perto pelos períodos imperial e republicano. O quarto ponto situa essas questões nas discussões e encaminhamentos subjacentes à elaboração e promulgação da LDBEN n. 9.394/96 e à subseqüente alteração do artigo 33, que orienta as questões relativas à disciplina de Ensino Religioso.

\section{Período colonial}

A partir da invasão portuguesa (1500), o processo educativo desenvolvido em solo brasileiro pelos mais de 300 povos indígenas foi alvo de ataques "colonial-civilizadores", que segundo Rampinelli (1999, p.31-32), visavam "arrancar as raízes destes povos, bem como apagar a memória histórica de suas lutas, seus triunfos, suas derrotas, seus heróis e seus mártires. Sabiam os europeus que um povo sem memória seria subjugado mais facilmente". Com algumas exceções, a conjugação entre a cruz (religião oficial) e a espada (poder constituído) portuguesas se dispôs ao ignóbil serviço de conquista e dominação desses povos, visando desestruturar seus sistemas político, econômico, cultural, moral e religioso. 
A compreensão formadora das comunidades indígenas que habitavam o território invadido foi ignorada em detrimento das exigências do pensamento colonizador. Para estes, os encontrados na terra tinham costumes selvagens, falavam por grunhidos e adoravam outros deuses. O escrivão da frota de Pedro Álvares Cabral, Pero Vaz de Caminha, ao encerrar sua carta ao Rei de Portugal, bem ilustra a compreensão portuguesa ao afirmar que:

(...) o melhor fruto que nela se pode fazer, me parece, que será salvar esta gente, e esta deve ser a principal semente que Vossa Alteza nela deve lançar [...]. (Apud FIGUEIREDO, 2000, p. 45)

Coube aos representantes eclesiásticos da Companhia de Jesus, por delegação da Coroa Portuguesa, a "educação" dos habitantes do território em processo de conquista, pelo exercício da catequese e instrução, pois de acordo com Mattos (1958, p.31), "dele dependeria (...) o êxito da arrojada empresa colonizadora; pois que somente pela aculturação sistemática e intensiva do elemento indígena aos valores espirituais e morais da civilização ocidental e cristã é que a colonização portuguesa poderia lançar raízes definitivas" na terra em ocupação.

A pedido de D. João III, a Companhia de Jesus, ordem fundada por Inácio de Loyola, envia o Padre Manoel da Nóbrega e mais cinco companheiros ao Brasil com a incumbência de formar um sistema de ensino público e gratuito, como também de catequizar os índios. Eles chegam ao seu destino em 1549 com o primeiro governador geral do Brasil Tomé de Souza. O sistema escolar por eles implantado seguiria os moldes comuns aos da Metrópole portuguesa também dirigida pela mesma ordem de religiosos. O programa de estudos era o prescrito pela Ratio Studiorum (Plano de Estudos), que visava uma formação humanista preconizada pelo processo da Contra-Reforma européia (GILES, 1987).

Inicialmente, de acordo com as pesquisas empreendidas por Ribeiro (1998), a proposta do Plano de Estudos organizado por Nóbrega apresentava a intenção de catequizar e instruir os indígenas, incluindo os filhos de colonos, assim como os mamelucos e os órfãos. Iniciava com o aprendizado da língua portuguesa, passando ao ensino da doutrina cristã, da leitura e da escrita, seguida do ensino do canto orfeônico e de música instrumental, estes dois de caráter opcional. O passo seguinte apresentava duas propostas: uma se referindo ao aprendizado profissional e agrícola e outra à aula de gramática e viagem de Estudos à Europa. O Plano de Estudos e sua aplicação encontraram sérias resistências a partir de 1556, com a emissão do documento "Constituições da Companhia de Jesus”. Estas questões muito exigiram de Nóbrega até a data de sua morte em 1570. 
A partir de 1570 até 1759, dá-se uma mudança radical no Plano de Estudos, sendo eliminadas deste as etapas iniciais. O Plano de Estudos publicado pela Companhia de Jesus em 1599 concentra sua programação nos elementos da cultura européia; optando pelos cursos de Humanidades, Filosofia e Teologia, culminando com uma viagem à Europa. Os interesses se concentram em pontos estratégicos, os filhos dos colonos em detrimento dos indígenas, os futuros sacerdotes em detrimento dos leigos. De acordo com Ribeiro (1998, p.25),

o plano legal (catequizar os índios) e o plano real se distanciam. Os instruídos serão descendentes dos colonizadores. Os indígenas serão apenas catequizados. (...) A catequese (...) interessava à Companhia como fonte de novos adeptos do catolicismo, (...) ao colonizador, à medida que tornava o índio mais dócil e, portanto, mais fácil de ser aproveitado como mão-de-obra.

São fundados seminários para a formação de sacerdotes membros da Companhia e a primeira escola para meninas e os colégios se destinam à formação de uma elite letrada. Ribeiro (1998) destaca que estes dedicavam especial atenção ao preparo dos professores, que somente se tornavam aptos aos trinta anos; selecionavam cuidadosamente os livros e exerciam rigoroso controle sobre as questões a serem suscitadas pelos professores, especialmente em filosofia e teologia. O objetivo era acima de tudo religioso, o seu conteúdo, literário e o método utilizado, o escolástico medieval, contribuindo para o afastamento de outras orientações religiosas e do espírito científico nascente, próprio do século XVII. Segundo a mesma autora (RIBEIRO, 1998, p.28),

o privilegiamento do trabalho intelectual em detrimento do manual afastava os alunos dos assuntos e problemas relacionados à realidade imediata, distinguindo-os da maioria da população que era escrava e iletrada e alimentava a idéia de que o mundo civilizado estava "lá fora" e servia de modelo. Os "letrados" acabavam por rejeitar não apenas esta maioria, e exercer sobre ela uma eficiente dominação, como também a própria realidade colonial, contribuindo para a manutenção deste traço de dominação externa e não para sua superação.

Segundo Zimmermann (1998), a Igreja Católica Apostólica Romana exerceu papel determinante na construção do sistema educacional brasileiro, tanto por ser considerada a religião oficial, quanto pela sua participação no processo colonial português. Segundo a historiografia oficial, a educação brasileira se manteve basicamente restrita aos seminários e colégios católicos até a expulsão dos jesuítas pelo Marquês de Pombal. 
Atualmente com o movimento revisionista da história ocorrida na América Latina, novos dados estão sendo acrescidos e demonstram que a história da educação brasileira conta com muitos atores relegados a um segundo plano; dentre os quais se destacam as atividades educativas e escolares diferenciadas dos jesuítas nas Sete Missões, desenvolvidas no sul do Brasil e no nordeste da Argentina até aproximadamente 1770. (LUGON, 1968)

Cabe destacar a noção de independência que desenvolviam entre os povos guaranis, promovendo com eles uma ação de natureza política com vistas à autonomia. Segundo Eduardo Galeano (1985), os resultados alcançados preocuparam as coroas portuguesa e espanhola a tal ponto, que imediatamente determinaram a eliminação das missões, através do Tratado de Madri. As instruções chegaram aos responsáveis religiosos nas missões em envelopes lacrados vindos de Madri e na calada da noite, mais de dois mil sacerdotes foram desterrados para a remota Itália a mando dos vice-reis e governadores. Ainda segundo o mesmo autor (1985, p.63),

os jesuítas tinham ensinado os guaranis a usar relógios, arados, sinos, clarinetes e livros impressos em sua própria língua guarani; mas também tinham ensinado os índios a fabricar canhões para se defender dos caçadores de escravos.

Após o desterro dos educadores jesuítas, o sistema comunitário de produção e vida, os bens comuns, como as igrejas, fábricas, escolas e livros, as plantações de mate e trigo, são dilapidados ou vendidos; "os índios fogem para a selva ou viram vagabundos, ou putas ou bêbados. Nascer índio volta a ser insulto ou crime" (GALEANO 1985, p.65).

Por parte da coroa portuguesa, Sebastião José de Carvalho Melo, 0 Marquês de Pombal, Primeiro Ministro de Portugal propunha como objetivo de sua reforma educacional a criação de uma escola prioritariamente útil ao Estado, que, antes de servir aos interesses da fé, servisse aos imperativos da Coroa. Preconizava o ensino público propriamente dito, ou seja, não mais 0 financiado pelo Estado formando os indivíduos para a igreja, mas financiado pelo e para o Estado. Segundo ele, a Companhia de Jesus se apresentava como empecilho na conservação da unidade cristã e civil, por ser detentora de um poder econômico a ser devolvido ao governo e por educar o cristão a serviço da igreja e não do país (RIBEIRO, 1998).

Diretamente atingida pelos editos da reforma educacional de Pombal, a Companhia de Jesus chega a ser expulsa do Brasil em 1759. 0 número de estabelecimentos de ensino pertencentes à Companhia de Jesus, por ocasião de sua expulsão difere de autor para autor. Para Carvalho (1952, p.139141), seriam quarenta e três missões, escolas de ler e escrever, estabeleci- 
mentos de ensino secundário, entre colégios e seminários; Ferreira (1966, p.218) refere-se a "vinte Colégios, doze Seminários, um Colégio e um Recolhimento feminino", enquanto Azevedo (1944, p.312) fala de "trinta e seis residências, 36 missões e 17 colégios e seminários menores e as escolas de ler e escrever". Com a transferência dos padres jesuítas para Portugal, esses estabelecimentos passaram a ser dirigidos por padres franciscanos e beneditinos que, entretanto, também se mostravam resistentes às idéias iluministas em desenvolvimento no continente europeu segundo as pesquisas de Junqueira (2002).

Com a reforma pombalina, pela emissão do Alvará de 28 de junho de 1759, é criado o cargo de diretor geral dos estudos; são designados comissários para a verificação do estado das escolas e professores; dá-se a prestação de exames para todos os professores (que passam a gozar dos direitos dos nobres); concurso para provimento das cátedras de latim e retórica; inquérito para identificação dos professores que estariam lecionando sem licença ou usando livros proibidos e a proibição de ensino público ou particular sem licença do diretor geral dos estudos (RIBEIRO, 1998).

\section{Período imperial}

Durante o período imperial surgiram as escolas imperiais e a historiografia oficial acusa a presença de uma incipiente rede de escolas públicas, para atender aos filhos da elite. No Brasil, a educação era privilégio de poucos e o analfabetismo era muito grande, ficando ainda maior após a expulsão dos jesuítas, pelo fato de as escolas imperiais não terem alcançado êxito em sua proposta de educar os brasileiros. Durante o período da Monarquia Constitucional, a Igreja se constituiu no principal respaldo do poder, estabelecido por conta do regime do padroado, que fazia do Imperador a autoridade maior da Igreja Católica do Brasil, sendo por isso a religião oficial do império; ela, contudo, não tinha autoridade sobre a educação pública (GILES, 1987).

Danilo Streck (1995) registra que, a partir de 1824, com a chegada dos imigrantes alemães luteranos, foram criadas mais de 400 escolas situadas junto às comunidades de colonos imigrantes instalados nos Estados do Rio Grande do Sul, Santa Catarina, São Paulo, Rio de Janeiro e no Espírito Santo. Estabelecendo-se nas novas terras, os imigrantes foram logo construindo escolas para seus filhos; primeiro porque a educação escolar fazia parte de sua bagagem cultural, depois devido ao fato de que no Brasil apenas uma parcela mínima da população tinha acesso às escolas (apenas 10\% em 1867). As escolas fundadas pelos imigrantes ministravam aulas em língua alemã e, por isso, não eram reconhecidas pelo Estado imperial. 
Lorenzetti (1998) menciona em sua pesquisa que durante o segundo império, sob a influência de diversas ordens religiosas, foram instalados diversos colégios particulares, alguns deles com regime de internato masculino e feminino. Além de separação por sexo, essas escolas ofereciam diferentes regimes e propostas pedagógicas.

O Ensino Religioso é mencionado pela primeira vez num documento oficial relativo à educação escolar em 15 de outubro de 1827, que "manda" criar escolas de "primeiras letras em todas as cidades, vilas e lugares mais populosos do Império". Destinava-se o mesmo a regulamentar o inciso XXXII do art. 179 da Constituição Imperial. No artigo 6ํㅡ, lia-se que,

os professores ensinarão a ler, escrever, as quatro operações de arithmética, prática de quebrados, decimaes, proporções, as noções, mais geraes de geometria prática, a gramática da língua nacional, e os princípios de moral christã e da doutrina da religião cathólica apostólica romana, proporcionados à compreensão dos meninos; preferindo para as leituras a Constituição do Império e a história do Brasil (IMPÉRIO DO BRASIL, 1996).

No período imperial Estado e Igreja Católica formaram uma parceria indisso ciável. A laicidade do Estado, promulgada com o regime republicano (1899), resultou na separação de ambos. Nesse contexto, de acordo com Zimmermann (1998), poder-se-ia dizer, em linhas gerais, que o Ensino Religioso (reconhecido pelo Estado) se apresentou em duas modalidades ao longo dessa trajetória histórica. Inicialmente, sob o regime do padroado e regalismo, numa perspectiva colonial-regalista, com um ensino religioso humanista-católico. Num segundo momento, durante o período republicano, sob a égide do pensamento liberal, o ensino religioso é mantido na escola pública, mas sua freqüência passa a ser opcional para o educando.

\section{Período republicano}

A primeira Constituição da República dos Estados Unidos do Brasil com base no pensamento positivista declara, no artigo 72, parágrafo 6, que "será leigo o ensino ministrado nos estabelecimentos públicos", passando o Ensino Religioso a ser uma das áreas fortemente polemizada nas discussões e encaminhamentos educacionais da então nova República. Segundo as pesquisas de Junqueira (2002), até a década de trinta os embates entre o clero e os dirigentes republicanos não chegavam a um consenso em relação à participação do Ensino Religioso no sistema educacional público. Isto somente vem a dar-se no governo de Getúlio Vargas, que baseado no "Pacto Lateranense" 
volta a admitir o Ensino Religioso na escola pública, por interesses meramente políticos. A Constituição de 1934 vem legislar que,

o Ensino Religioso será de matrícula facultativa e ministrado de acôrdo com os princípios da confissão religiosa do alunno, manifestada pelos paes e responsáveis, e constituirá matéria dos horários nas escolas públicas primarias, secundárias, profissionaes e normaes (REPÚBLCA DOS ESTADOS UNIDOS DO BRASIL, 1996).

A educação brasileira continuava, entretanto, sendo praticamente orientada pelas escolas religiosas até a década de trinta, uma vez que os docentes, na sua maioria, eram oriundos de escolas particulares religiosas, que primavam por uma sólida formação religiosa a subsidiar seus currículos. Com a criação do Ministério da Educação e da Saúde uma série de medidas reformistas passou a gerenciar e encaminhar a organização de um sistema de ensino público brasileiro (RIBEIRO, 1998).

Em relação às escolas privadas, a partir de 1914, com a deflagração da primeira guerra mundial, as verbas alemãs que mantinham esses educandários foram suprimidas, obrigando muitas delas a encerrar as atividades educacionais. Em 1930, o decreto da nacionalização das escolas foi responsável pelo fechamento de muitas delas, em sua grande parte, luteranas pelo fato de não terem professores que dominassem a língua portuguesa. Nas escolas católicas, afirma Lorenzetti (1998), padres e irmãs brasileiros logo assumiram a direção e a docência das escolas, impedindo o fechamento e garantindo a continuidade mesmo durante o período da segunda guerra mundial.

Ainda no âmbito do ensino privado, de acordo com o educador e pesquisador Danilo Streck (1995, p.39-65, cabe registrar a criação de educandários em diferentes pontos do país, como decorrência do trabalho educacional de outras denominações religiosas que foram se estabelecendo em solo brasileiro no período pré-republicano e republicano. Os educadores metodistas fundaram escolas no período de 1880 a 1904; nas cidades de Juiz de Fora, Piracicaba (hoje UNIMEP), Petrópolis, Ribeirão Preto e Belo Horizonte. Colégios evangélicos da Igreja Presbiteriana Independente foram fundados a partir de 1870; em São Paulo, Piracicaba, Rio de Janeiro, Juiz de Fora e Porto Alegre. O trabalho batista referente à área da educação passou por estágios diferenciados no período de 1888 a 1898, contando em 1992 com cerca de 60 escolas de primeiro e segundo graus. A Igreja Anglicana desenvolveu trabalho educacional no Rio Grande do Sul, desde 1916, constituindo-se hoje no Colégio Santa Margarida de Pelotas. Os motivos para tais empreendimentos situavamse, entre outros, no âmbito da necessidade de escolarização, contribuição missionária ao país em desenvolvimento e proposta de Ensino Religioso diferenciado ao vigente (católico) para os seus fiéis. 
Em todas as modalidades, o Ensino Religioso ministrado nas escolas brasileiras sempre foi de cunho confessional, excetuando algumas iniciativas diferentes como as propostas interconfessionais, particularmente na região sul do país, conforme declara Anísia de Paulo Figueiredo (1994). A historiadora aponta que, a partir da promulgação da Lei 5692/71, os Estados do sul do Brasil buscaram outras perspectivas pedagógicas, levando em conta uma escola aberta a diferentes credos, embora o cristianismo continuasse sendo 0 marco referencial da proposta em si. Em conseqüência do processo imigratório, o contexto cultural-religioso presente nesses Estados se fazia sentir também no ambiente escolar através de uma convivência entre cristãos de diferentes credos religiosos. Essa convivência acontecia de forma espontânea, facilitando o diálogo e favorecendo a prática de um Ensino Religioso de ordem ecumênica. Foram criadas propostas de formação para os professores e materiais didáticos com uma linguagem diferenciada daquela adotada pela maioria até então. Os Estados do Rio Grande do Sul, Santa Catarina e Paraná foram forças motrizes neste processo.

Os ventos favoráveis que advinham do Movimento Ecumênico Internacional, em especial da criação do Conselho Mundial de Igrejas (1948) e do Concílio Ecumênico Vaticano II (1962-1965), em muito contribuíram para a organização destas iniciativas diferenciadas.

No Brasil, segundo Junqueira (2000) e Caron (1997), a formação de docentes em Ensino Religioso até a década de 90 era orientada quase que na sua totalidade pelas denominações religiosas cristãs e, em alguns casos, ela ocorria em parceria com os sistemas de ensino. Isto se dava em decorrência da linha confessional e/ou interconfessional que era adotada por esta disciplina, em consonância com a legislação vigente. $O$ interesse e a participação das diversas denominações religiosas cristãs na formação desses professores foi um movimento marcante na história da educação brasileira.

Em pesquisa desenvolvida acerca desta temática, a catarinense Lurdes Caron (1997) registra que, para atender à necessidade da contínua formação de professores de Ensino Religioso, desenvolviam-se cursos de Teologia, Ciências Religiosas, Catequese, Educação Cristã e outros similares. Essa ação, também por parte das Igrejas, ficava condicionada à ajuda financeira do exterior e/ou recursos do próprio professor. A pesquisadora destaca as experiências do Curso Superior em ER do Pará, de Pedagogia Religiosa do Paraná e de Aprofundamento para Professores de ER em Santa Catarina.

Ainda de acordo com a mesma autora (1997), é necessário mencionar que esse tipo de formação, apesar do esmero e qualidade, não graduava os professores em conformidade com os profissionais da educação de outras disciplinas, gerando impasses e dificuldades na vida funcional deles. Os professores das outras disciplinas tinham suas graduações reconhecidas pelo Mi- 
nistério da Educação e Cultura (MEC), dando-lhes direito ao ingresso por concurso público e, em conseqüência, de seguir plano de carreira funcional. Os professores de Ensino Religioso, embora muitas vezes formados por cursos de caráter teológico, não tinham reconhecimento por parte do MEC. Por imperativo da legislação, eram-lhes negados os acessos funcionais na área do magistério, sendo apenas permitida a contratação de seus serviços em caráter temporário.

\section{A LDBEN n. 9.394/96 e a formação de docentes para o Ensino Religioso}

Uma das fortes temáticas a envolver toda a reforma educativa brasileira, desencadeada a partir da década de oitenta, abordava a pluralidade cultural religiosa ${ }^{3}$ presente nas escolas brasileiras e, em conseqüência da mesma, a necessidade de uma proposta de Ensino Religioso que integrasse esse referencial.

A reflexão sobre o Ensino Religioso que levava em consideração esse contexto propiciava uma abordagem diferenciada dessa disciplina, onde 0 acesso do conhecimento religioso sistematizado historicamente pela humanidade é assegurado a todo cidadão.

Como um dos resultados desses estudos e reflexões coletivos, no ano de 1995 são elaborados os Parâmetros Curriculares Nacionais de Ensino Religioso (PCNER) e aprovados pelo Plenário do Fórum Nacional Permanente de Ensino Religioso (FONAPER) ${ }^{4}$, na sua terceira sessão em Piracicaba, cidade do Estado de São Paulo, no mês de março do ano de 1996. Esse documento apresenta os referenciais para um Ensino Religioso que,

valorizando o pluralismo e a diversidade cultural presentes na sociedade brasileira, facilita a compreensão das formas que exprimem o Transcendente na superação da finitude humana e que determinam, subjacentemente, 0 processo histórico da humanidade; (...) porisso não deve ser entendido como Ensino de uma Religião ou das Religiões na Escola, mas sim uma disciplina centrada na antropologia religiosa. (FONAPER, 1997, p. 30 e 11)

3 Interessante reflexão sobre o uso da terminologia "pluralidade/pluralismo religioso cultural", utilizada nos documentos educacionais brasileiros é encontrada na dissertação de mestrado de Roseli BLANCK, O Ensino Religioso mediante a pedagogia de projetos face à pluralidade cultural religiosa brasileira, p. 12-18.

4 O FONAPER é "uma sociedade civil de âmbito nacional, sem vínculo político-partidário, confessional e sindical, sem fins lucrativos, sem prazo determinado de duração, que congrega, conforme este Estatuto, pessoas jurídicas e pessoas físicas identificadas com o Ensino Religioso Escolar e se constitui em um organismo que trata questões pertinentes ao Ensino Religioso ER, sem discriminação de qualquer natureza.” FONAPER, Estatuto, cap. I, art. 1. 
A realidade brasileira, naquele momento, encontrava-se marcada por indefinições políticas, profundas desigualdades sociais e múltiplas contradições em áreas da atuação educacional. Propostas para uma educação que privilegiasse o ser humano de forma plena, buscando o seu desenvolvimento integral: físico, psíquico, cognitivo, afetivo, religioso, social, político e econômico, apresentavam-se como pistas para uma práxis transformadora, cuja qualidade, com certeza, enseja a construção de uma sociedade em que o ser humano se apresenta como sujeito e autor da própria história.

A LDBEN n. 9.394, promulgada em 20 de dezembro de 1996, no seu artigo 33, formulava que,

O ensino religioso, de matrícula facultativa, constitui disciplina dos horários normais das escolas públicas de ensino fundamental, sendo oferecido sem ônus para os cofres públicos, de acordo com as preferências manifestadas pelos alunos ou por seus responsáveis, em caráter (...) confessional (...) ou interconfessional.

Segundo Zimmermann (1998) e Junqueira (2002), a diversidade cultural religiosa da população brasileira e a compreensão de Ensino Religioso como um dos componentes curriculares a contribuir para "o pleno desenvolvimento do educando, seu preparo para o exercício da cidadania e sua qualificação para o trabalho" (LDBEN n.9.394/96, Art. 2.․o); suscitaram questionamentos sobre a omissão do Poder Público sob o ponto de vista pedagógico e financeiro, expressos na redação do referido artigo.

As pesquisas de Junqueira (2002) apontam que, a partir das muitas solicitações e discussões com entidades religiosas e civis, professores e comunidade em geral, foram encaminhadas três proposições de mudança do texto da lei à Câmara Federal.

O Projeto de Lei n. 2.757/97, de autoria do deputado Nelson Marchezan (PSDB-RS), não pretendia introduzir grandes mudanças na lei, mas apenas a retirada da expressão "sem ônus para os cofres públicos".

O Projeto de Lei n. 2.997/97 de autoria do Deputado Maurício Requião (PMDB-PR), propunha alterações significativas na redação do artigo 33; tais como a integração do Ensino Religioso na formação básica do cidadão, proibição de qualquer forma de doutrinação ou proselitismo, respeito à pluralidade brasileira, de acordo com os PCNs e as entidades representativas das diversas denominações religiosas.

O Projeto de Lei n. 2.997/97, de autoria do Poder Executivo, propunha a permanência do texto de lei em si, não sendo aplicado quando o Ensino Religioso fosse de caráter ecumênico, de acesso a conhecimentos promovendo a educação da dimensão religiosa. Encaminhava à definição de procedi- 
mentos e conteúdos, formas de treinamento, recrutamento e remuneração dos professores para a competência de cada sistema de ensino, admitindo parceria total ou parcial, com a entidade civil constituída pelas diferentes denominações religiosas.

O então Deputado Roque Zimmermann (PT-PR), membro da Comissão de Educação, Cultura e Desporto, foi indicado relator do processo. Com base nos projetos anteriores, estudos e contatos com o FONAPER, ele apresentou o substitutivo de lei, promulgado em 22 de julho de 1997, sem utilizar novas terminologias e respeitando o espírito das discussões desenvolvidas.

O FONAPER, instalado em 25 de setembro de 1995 na Cidade de Florianópolis (SC), durante a celebração do jubileu do Conselho de Igrejas para o Ensino Religioso (CIER $)^{5}$; contando com a presença de representantes dos Sistemas de Ensino, Instituições civis e religiosas, coordenadores e professores de Ensino Religioso e pessoas comprometidas com esta temática provenientes de dezoito Estados brasileiros, foi elemento determinante nesse processo de finalização dos encaminhamentos do substitutivo de lei.

De acordo com seus estatutos, o FONAPER (capítulo I, art. 1) congrega pessoas jurídicas e pessoas físicas identificadas com o Ensino Religioso, se constituindo em um organismo que trata das questões pertinentes ao Ensino Religioso sem discriminação de qualquer natureza. Neste sentido, no decorrer do ano de 1995 e 1996 o FONAPER foi responsável pela elaboração dos Parâmetros Curriculares Nacionais de Ensino Religioso (PCNER), que subsidiaram os debates e encaminhamentos das propostas de lei para o Ensino Religioso na elaboração da nova LDBEN promulgada em 20/12/96, assim como a subseqüente alteração de redação do artigo 33 (JUNQUEIRA, 2000).

O processo deflagrado resultou na aprovação da Lei n. 9.475 promulgada em 22/07/97, e alterou significativamente os encaminhamentos dessa

5 O Conselho Interconfessional de Igrejas para o Ensino Religioso, criado em 1972 no Estado de Santa Catarina, é "uma associação religiosa de âmbito estadual com fins educacionais, filantrópicos e culturais" que juntamente com a Secretaria da Educação do Estado catarinense conduziu os trabalhos pertinentes à disciplina de Educação Religiosa Escolar, no tocante à organização de programas, conteúdos e formação de professores até a promulgação da LDBEN 9394/96. Em 1979, a nomenclatura passou a significar Conselho de Igrejas para o Ensino Religioso. Cf. Lurdes CARON, Entre conquistas e concessões, p. 45-60.

Após a promulgação da atual $\mathrm{LDBEN}$, esse Conselho passou a ter como principal objetivo fomentar a reflexão ecumênica no Estado e sua nomenclatura passou a representar Conselho de Igrejas para Estudo e Reflexão. Isto se deu em razão do entendimento das Igrejas integrantes do CIER em relação às orientações do artigo 33 da LDBEN 9394/96. Na assembléia extraordinária de 09/12/1997, realizada na cidade de Florianópolis, ficou estabelecido que no Estado seria criado o Conselho de Ensino Religioso (CONER), responsável doravante por conduzir as questões pertinentes ao Ensino Religioso. Formariam esse Conselho, representantes das tradições religiosas radicadas no Estado de Santa Catarina. Cf. CIER, Livro de atas/1997, p. 62-64. 
disciplina curricular. No dizer de Zimmermann (1998, p.10), foram criadas pela primeira vez na história brasileira,

oportunidades de sistematizar o ensino religioso como disciplina escolar que não seja doutrinação religiosa e nem se confunda com o ensino de uma ou mais religiões. Tem como objeto a compreensão da busca do transcendente e do sentido da vida, que dão critérios e segurança ao exercício responsável por valores universais, base da cidadania.

O texto de lei, que dá nova redação ao artigo 33 da LDBEN n. 9.394/ 96, assim ficou estabelecido:

Art. 33 - O ensino religioso, de matrícula facultativa, é parte integrante da formação básica do cidadão, constitui disciplina dos horários normais das escolas públicas do ensino fundamental, assegurando o respeito à diversidade cultural religiosa do Brasil, vedadas quaisquer formas de proselitismo.

$\S 1$. Os sistemas de ensino regulamentarão os procedimentos para a definição dos conteúdos do ensino religioso e estabelecerão as normas para a habilitação e admissão dos professores.

$\S 2$. Os sistemas de ensino ouvirão entidade civil, constituída pelas diferentes denominações religiosas, para a definição dos conteúdos do ensino religioso (BRASIL, 1997).

Segundo Junqueira (2002), a mudança de paradigma na concepção do Ensino Religioso, a elaboração dos PCNER e a busca de definição de Diretrizes Curriculares Nacionais para a formação de docentes para esta área do conhecimento, junto ao Ministério da Educação e Cultura passaram a exigir novas propostas de formação docente para esta área do conhecimento. Nesse sentido, registrou-se o emergente interesse, compromisso, estudo e discussão em busca de parcerias suscitado nas denominações religiosas, na comunidade acadêmica e nos sistemas de ensino no que concerne aos encaminhamentos previstos em forma de lei para a habilitação dos professores de Ensino Religioso.

A nova redação do artigo 33 da LDBEN n. 9.394/96, prescrita na forma da Lei 9.475/97, veio, portanto, contemplar ambas as questões, não excluindo a valiosa colaboração das diferentes denominações religiosas, no que se refere à definição dos conteúdos para a disciplina de Ensino Religioso.

Na construção das parcerias para a formação de docentes em Ensino Religioso, o dispositivo legal (BRASIL, 1997) congrega os sistemas de ensino que deverão regulamentar os procedimentos para a definição dos conteúdos do Ensino Religioso e estabelecer as normas para a habilitação e admissão dos professores. As diferentes denominações religiosas constituídas em entidade civil serão ouvidas pelos sistemas de ensino, no tocante à definição dos con- 
teúdos da disciplina. As Instituições de Ensino Superior, em sintonia com eles, têm a tarefa de habilitar o profissional correspondente, fomentando o ensino, a pesquisa e a extensão dos mesmos.

A partir dessa nova configuração histórica, conforme relato de Wagner (1996), a grande preocupação doravante seria a de preparar o profissional que atuasse como professor de Ensino Religioso. Em 1997, o FONAPER já havia encaminhado às Universidades brasileiras uma Proposta de Diretrizes Curriculares para a Formação de Professores para o Ensino Religioso, com base nos Parâmetros Curriculares Nacionais de Ensino Religioso. Segundo Junqueira (2002b, p.98), percebia-se na realidade, "cada vez mais a urgência de uma sólida e adequada formação dos professores de Ensino Religioso, que devem ter uma formação própria de licenciados".

Santa Catarina era um dos Estados que há mais de duas décadas já vinha buscando formas de criar um curso de licenciatura voltado para o Ensino Religioso. Integrado com este movimento em nível nacional, faz outra tentativa a partir da diretoria do CIER e representantes dos professores de Ensino Religioso e da Secretaria da Educação do Estado, sendo desta vez junto à Universidade Regional de Blumenau (FURB) em meados de 1995.

De acordo com Caron (1997), as discussões sobre a necessidade de um curso em nível superior para habilitar os professores de Educação Religiosa no Estado de Santa Catarina iniciaram em 1970. Em 1972, o CIER encaminhou o primeiro projeto de Curso de Licenciatura de $1^{\underline{0}}$ grau em Educação Religiosa Escolar ao Conselho Federal de Educação, sendo a sua autorização negada em razão de interpretação de texto de lei. Outras tentativas em nível estadual aconteceram nos anos de 1973 e de forma intensiva entre os anos de 1985 a 1990.

Uma nova solicitação à outra Universidade de Santa Catarina apresentava-se como mais uma tentativa/possibilidade em suprir uma necessidade de longa data, desafio e compromisso sempre presentes nas atividades desse grupo durante os últimos vinte e cinco anos.

A portaria 37/96 emitida pelo reitor da FURB, datada de 22 de março de 1996, designou a “Comissão Especial de Estudos, destinada à montagem do projeto de viabilidade do Curso de Ciências Religiosas, nomeada pela portaria 35/96, de 20/03/96". Estavam dados os primeiros passos para a criação do atual Curso de Ciências da Religião - Licenciatura Plena em Ensino Religioso no Estado de Santa Catarina.

Ainda no decorrer do ano de 1996, duas outras Universidades do Estado, a Universidade da Região de Joinville (UNIVILLE) e a Universidade do Sul de Santa Catarina (UNISUL), também empreenderam processo similar no que concerne à criação de curso de formação docente para esta área do conhecimento. 
Nos mês de novembro do mesmo ano, as primeiras duzentos e cinqüenta (250) vagas, distribuídas nas três Universidades, foram disponibilizadas via Concurso Vestibular aos professores de Ensino Religioso das Redes Municipal e Estadual do Estado catarinense, via Convênio Projeto Magister ${ }^{6}$.

Aos vinte de dezembro de 1996 era promulgada a LDBEN n. 9.394/ 96, que viria legislar a necessidade de uma formação concernente para esta disciplina. Dois anos após o CNE, a partir da Resolução 02/98, instituía em suas Diretrizes para o Ensino Fundamental a Educação Religiosa, na forma da nova redação do artigo 33 (Lei n. 9475), como área do conhecimento. Neste sentido, de acordo com a legislação nacional (LDBEN n. 9.394/96, art.72) para as demais áreas do conhecimento, a formação de docentes para a disciplina de Ensino Religioso, indubitavelmente deveria passar pela formação em nível superior, em cursos de licenciatura de graduação plena.

Pela primeira vez na história brasileira a formação de docentes para 0 Ensino Religioso trilharia os mesmos passos e seguiria os trâmites previstos em legislação para a formação de profissionais das demais áreas de conhecimento; assegurando aos seus egressos os direitos concernentes aos profissionais da educação e disponibilizando a sociedade brasileira uma formação para a cidadania que integra o estudo do fenômeno religioso na pluralidade cultural, buscando o pleno desenvolvimento de seus educandos.

No decorrer dos anos, outros Estados da federação também apresentando tessituras histórias de longa data similares às de Santa Catarina foram elaborando seus Cursos de Licenciatura em Ensino Religioso e/ ou buscando o reconhecimento de cursos já em andamento (como por exemplo, o Estado do Pará), mediante adequações à legislação em vigor.

O envolvimento de Universidades, Secretarias de Educação, FONAPER, Grupos Educacionais e Religiosos comprometidos com uma educação de efetiva participação no desenvolvimento da sociedade brasileira, não tem se limitado às questões relativas à formação inicial de docentes para o Ensino Religioso, mas se ampliam e completam com propostas e ações de formação continuada e com pesquisas para esta área do conhecimento ${ }^{7}$.

Muitos e diferenciados são os desafios postos. O lastro histórico que subsidia e constitui uma área de conhecimento, ao mesmo tempo, que a impulsiona e mobiliza na organização de novas tramas e tessituras, também pode inibi-la e constrangê-la na efetivação delas.

6 O Projeto MAGISTERé um programa de incentivo à formação docente em nível superior, que entre suas seis ações básicas, conta com a oferta de "cursos de graduação plena e formação em caráter emergencial nas áreas do conhecimento mais carentes de professores habilitados". Cf. SANTA CATARINA, Parecer SED n. 141/9.

7 Vide site www.fonaper.com.br 


\section{Uma história em meio a muitas histórias: puxando os fios}

Ler uma história é tarefa muito árdua e delicada, pois esta carrega em suas entranhas todo o movimento e respirar de vidas; que entretecidas nos labores, lutas, dores e prazeres do cotidiano, foram definindo o tracejado de um espaço sem fronteiras, uma vez que suas margens se encontram e se perdem nas margens de outras histórias. Enganam-se os que, movidos por afoiteza e olhares limítrofes, reduzem a história a uma mera seqüência lógica de fatos, datas e/ou uma sucessão das conquistas do poder e dos atos de poder.

Buber (1982, p.121) rompe com essa visão reducionista e utilitarista quando situa a história como o "encadeamento das responsabilidades do poder no decorrer do tempo". O autor desloca a percepção de história de uma leitura linear para uma leitura sistêmica; desvela uma outra faceta que na verdade é o substrato que a move e produz, ou seja, as diferentes conjugações, enquanto presenças e ausências, das responsabilidades do poder no distender-se no espaço/tempo.

A história da formação de docentes para o Ensino Religioso no Brasil, enquanto componente curricular vista de forma breve neste texto, pode ser lida sob muitos ângulos.

As raízes do pensamento educacional europeu se fizeram presentes e foram determinantes durante um longo período nestes mais de 500 anos de história brasileira. As contribuições dos mais de 300 povos habitantes da terra foram aproveitadas e incorporadas na medida em que atendiam aos interesses da matriz política e ideológica. Conquistas e atos de poder quando não as dizimaram, visaram mutilar suas entranhas para que seus suspiros não mais exalassem lições de sabedoria entretecidas com conhecimentos acerca de ser humano, educação e vida, perigoso combustível para rebeliões e possíveis levantes de ignorantes e incultos (RAMPINELU, OURIQUES, 1999; MORIN, 2000; MELIÁ 1992).

Conquistas e atos de poder geram a necessidade insana de novos e hediondos atos de conquistas, assim como formas de usurpar e tripudiar com o poder. A cultura negra, adentrando por imposição em território brasileiro, trouxe consigo valiosas e novas possibilidades de abertura de horizontes no campo econômico, cultural e religioso para a colônia portuguesa aqui radicada. Entretanto, seus múltiplos conhecimentos foram invisibilizados e reduzidos a mero trabalho braçal, sua sabedoria e religiosidade minimizada e transfigurada em atos de magia e ocultismo (SILVA, 1992).

A exemplo de outras áreas de conhecimento, também na formação de docentes para o Ensino Religioso, durante alguns séculos determinadas leituras, autores e contextos foram privilegiados em detrimento de outros. A 
influência das escolas européias foi determinante por um longo período e o âmbito de muitos conhecimentos ficou restrito e fragmentado em função de alguns limites postos.

De acordo com Wagner (1999), muitas vezes em resposta aos urgentes desafios do cotidiano, ao abrirmos trilhas na floresta ameaçadora, não atentamos para a riqueza e as respostas já presentes nas margens. Os ventos favoráveis do movimento ecumênico internacional na década de cinqüenta e sessenta trouxeram alento e possibilidades redobradas para uma América Latina em dores que, grávida de esperanças seculares, reclamava por ações encarnadas que no seu contexto cotidiano estivessem radicalmente comprometidas com a vida plena.

As margens começaram a ser revisitadas, visibilizadas e ressignificadas, uma vez que estas, na sua origem, compunham o todo dilacerado e sacrificado ao se construir a trilha. Timidamente e com muito receio, em meio a dores e marcas históricas, a vida foi se fazendo presente no seu eterno teimar por renascer. No âmbito do Ensino Religioso e conseqüentemente no da formação de docentes para esta área do conhecimento novas possibilidades foram sendo gestadas.

Uma profunda reflexão é desencadeada em relação à identidade do Ensino Religioso escolar. Algumas dessas reflexões começaram a encontrar eco em diversos pontos da federação e dar início a uma construção diferenciada nos currículos e orientações aos professores responsáveis por essa disciplina nas Unidades Escolares. Paulatinamente um novo entendimento vai sendo gestado a partir de outros olhares, novas abordagens e de inclusões. Muitos foram e são desde então, os desafios, embates e necessidades deflagrados no âmbito epistemológico e pedagógico em decorrência dos diferentes posicionamentos tomados.

Muitos desses desafios se apresentam em função de limites postos como a complexidade, exclusão e contradições no processo de formação de docentes no Brasil; a pouca caminhada histórica na formação de docentes para esta área do conhecimento, o número restrito de estudos e pesquisas a subsidiá-las, entre outros. De forma paralela, ações e propostas em construção oportunizam diferentes perspectivas e desenhos na tessitura em desenvolvimento e apontam para compromissos com a criação de novos tempos, espaços e possibilidades.

Embora inserido numa transitoriedade histórica própria, o traçado em delineamento exige "riscos" ${ }^{\prime \prime}$ capazes de refletir e projetar, com ética e

8 Para Lúcio Costa, arquiteto brasileiro de renome internacional "risco é desenho não só quando quer compreender ou significar, mas 'fazer', construir. (...) o risco - o traço é tudo, tem carga, é desenho com uma determinada intenção - é o design". Os antigos empregavam a palavra "risco", significando projeto como por exemplo: o "risco para a capela de São Francisco". Lúcio COSTA. Registro de uma vivência, p. 39. 
responsabilidade, a intencionalidade deste trabalho que, apesar da sua fragilidade e tenra idade, integra a tessitura da formação de docentes para o Ensino Religioso no século XXI.

O desafio de Buber permanece latente, mobilizando reflexões e ações que venham a configurar, no encadeamento das responsabilidades do poder de muitos, uma história que possa revelar a participação, contribuição e interesses de todos.

\section{Referênciais}

AZEVEDO, Fernando de. Acultura brasileira: introdução ao estudo da cultura no Brasil. 2. ed. São Paulo, SP: Companhia Editora Nacional, 1944. P. 529.

BLANCK, Roseli. 0 ensino religioso mediante a pedagogia de projetos face à pluralidade cultural religiosa brasileira. 1999. Dissertação (Mestrado em Teologia) - Escola Superior de Teologia, São Leopoldo, 1999.

BRASIL Constituição (1988). Constituição da República Federativa do Brasil: promulgada em 5 de outubro de 1988. Rio de Janeiro, RJ: Degrau Cultural, 1988. p. 111.

BRASIL Lei n. 9.394, 20 de dezembro de 1996. Estabelece as Diretrizes e Bazes da Educação Nacional. Lex: Diário Oficial da União, Brasília, DF: 1996.

BRASIL Lei n. 9.475, 22 de julho de 1997. Dá nova redação ao art. 33 da Lei n. ${ }^{0}$ 9.394, de 20 de dezembro de 1996, que estabelece as diretrizes e bases da educação nacional. Lex: Diário Oficial da União, Brasília, DF: 1997.

CONSELHO Nacional De Educação. Institui as Diretrizes Curriculares Nacionais para o Ensino Fundamental. Resolução n. 2, 07 de abril de 1998. Lex: Diário Oficial da União, Brasília, DF: Seção 1, 15 de abril de 1998. p. 31.

BUBER, Martin. Do diálogo e do dialógico. Tradução de Marta Ekstein de Souza Queiroz e Regina Weinberg. São Paulo, SP: Perspectiva, 1982. p. 171. (Coleção Debates).

CARON, Lurdes. Entre conquistas e concessões: uma experiência ecumênica em educação religiosa escolar. São Leopoldo: Sinodal, 1997. p. 176.

CNBB. O ensino religioso. São Paulo, SP: Paulinas, 1988. p. 199.

COSTA, Lúcio. Registro de uma vivência. In: COSTA, Maria Elisa. Com a palavra, Lúcio Costa: roteiro e seleção de textos Maria Elisa Costa. Rio de Janeiro, RJ: Aeroplano, 2001. p. 167. 
CARVALHO, Laerte R. As reformas pombalinas da instrução pública. Boletim da USP, São Paulo, n. 1, p. 202. 1952.

FERREIRA, Tito L História da educação luso-brasileira. São Paulo, SP: Saraiva, 1966. p. 287.

FIGUEIREDO, Anísia de Paulo. Ensino religioso: perspectivas pedagógicas. Petrópolis: Vozes, 1994. p. 126.

FIGUEIREDO, Anísia de Paulo. Ensino Religioso no Brasil hoje. Jornal Contex to Pastoral, Rio de Janeiro, p. 5, 1996.

FIGUEIREDO, Anísia de Paulo. O tema gerador no currículo de educação religiosa: o senso do simbólico. Petrópolis: Vozes, 2000. p. 85.

UNIVERSIDADE Regional de Blumenal. Projeto de autorização do curso de Licenciatura em Ciências da Religião: habilitação em Ensino Religioso. Blumenau: FURB. 1996. p. 178.

FÓRUM Nacional Permanente de Ensino Religioso. Estatuto do FONAPER. Brasília, DF: FONAPER, 2000.

FÓRUM Nacional Permanente de Ensino Religioso. Parâmetros Curriculares Nacionais para o Ensino Religioso. 3. ed. São Paulo, SP: Ave Maria, 1998. p. 63.

FÓRUM Nacional Permanente de Ensino Religioso. Proposta para as Diretrizes Curriculares dos Cursos Superiores na Área do Ensino Religioso. B rasília, DF: FONAPER. 1998. p. 35.

GALEANO, Eduardo. As caras e as máscaras. Tradução de Eric Nepomuceno. Rio de Janeiro, RJ: Nova Fronteira, 1985. p. 368.

GILES, Thomas Ransom. História da educação. São Paulo, SP: EPU. 1987. p. 304.

IMPÉRIO DO BRASIL. Documentos complementares do Império do Brasil. 15 de outubro de 1827. In: BONAVIDES, P., AMARAL, R. Textos Políticos da História do Brasil. Brasília, DF: Senado Federal, 1996. v. 8.

JUNQUEIRA, Sérgio R. A. Ensino Religioso: um histórico processo. In: Luís ALVES, Sérgio R. JUNQUEIRA (Org.). Educação Religiosa: construção da identidade do ensino religioso e da pastoral escolar. Curitiba: Champagnat, 2002. p. 245.

. O processo de escolarização do ensino religioso no Brasil. Petrópolis: Vozes, 2002. p. 159. 
LORENZETTI, Altair Anacleto. Romanização do Catolicismo (1890-1930) e Educação do Brasil: um estudo de caso: os franciscanos. Curitiba: PUCPR. 1998.

LUGON, C. A república comunista cristã dos guaranis (1610-1768). Tradução de Álvaro Cabral. Rio de Janeiro: Paz e Terra, 1968. p. 353.

MATTOS, Luiz de. Primórdios da educação no Brasil: o período heróico (1549-1570). Rio de Janeiro, RJ: Aurora, 1958. p. 306.

MORIN, Edgar. Saberes globais e saberes locais: o olhar transdisciplinar. Tradução de Paula Yone Stroh. Rio de Janeiro, RJ: Garamond, 2000. p. 73.

OLVEIRA, Lílian Blanck. Formação de docentes para o ensino religioso: perspectivas e impulsos a partir da ética social de Martinho Lutero. São Leopoldo: Escola Superior de Teologia, 2003.

RAMPINELU, Waldir.; OURIQUES Nildo Domingos (Orgs.). Os 500 anos: a conquista interminável. Petrópolis: Vozes, 1999. p. 120.

REPÚBLCA dos Estados Unidos do Brasil. Constituição da República dos Estados Unidos do Brasil. 16 de julho de 1934, In: BONAVIDES, P. AMARAL, R. Textos Políticos da História do Brasil, v. 8. Brasília, DF: Senado Federal, 1996.

RIBEIRO, Maria Luisa Santos. História da educação brasileira: a organização escolar. 8. ed . São Paulo, SP: Cortez: Autores Associados, 1998.

STRECK, Danilo R. Educação e igrejas no Brasil: um ensaio ecumênico. São Leopoldo: Sinodal, 1995. p. 92.

WAGNER, Raul. Fórum Nacional Permanente de Ensino Religioso. Revista Diálogo, n. 2, p. 62-63, 1996.

WAGNER, Raul. Seminário sobre Diretrizes Curriculares para o Ensino Religioso. São Francisco do Sul, SC: 1999.

ZIMERMANN, Roque. Ensino religioso: uma grande mudança. Brasília, DF: Câmara dos deputados, 1998. p. 14.

ZWETSCH, Roberto (Org.). $\mathbf{5 0 0}$ anos de invasão, $\mathbf{5 0 0}$ anos de resistência. São Paulo, SP: Paulinas, 1992. p. 320.

Recebido em: 22/03/2005. Aprovado em: 20/06/2005. 